\title{
РЕЦЕНЗІЯ \\ На монографію С. В. Кудіна на тему: «Порівняльна історія права: вітчизняна традиція концептуалізації»
}

\begin{abstract}
ЛОЩИХІН Олександр Миколайович - доктор юридичних наук, професор, професор кафедри менеджменту Межрегіональної академії управління персоналом, Заслужений економіст України
\end{abstract}

DOI:10.32782/LAW.2019.3.25

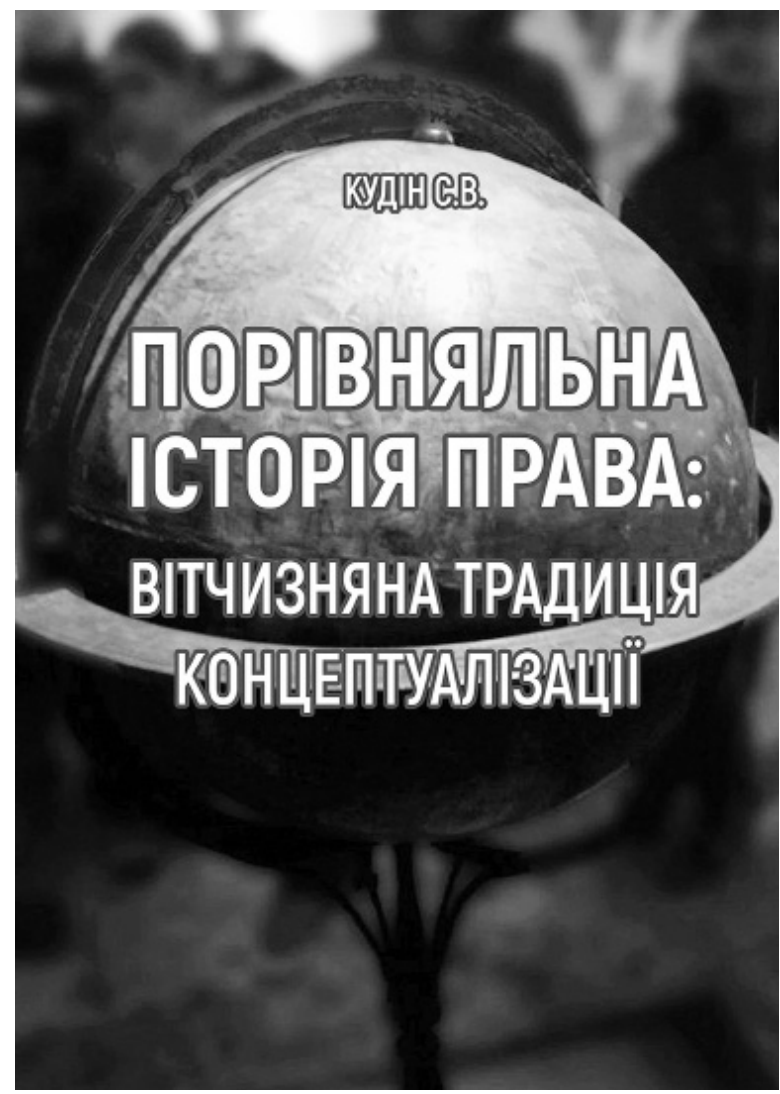

Монографія «Порівняльна історія права: вітчизняна традиція концептуалізациї» підготовлена Кудіним Сергієм Володимировичем, кандидатом юридичних наук, доцентом, доцентом кафедри теорії, історії права і держави та конституційного права Університету державної фіскальної служби України
Актуальність обраної С.В. Кудіним теми монографічного дослідження визначається низкою факторів об'єктивного характеру, найголовнішими серед яких можемо виділити: світоглядні, звичаєві, психологічні, міжнародні, які проявляються на сучасному етапі розвитку людства, та інші. Це зумовлює і характер та спрямованість обраної теми монографії, а іiі значущість - також і недостатньою розробленістю у вітчизняній історично-правовій науці.

У передмові С.В. Кудін достатньою мірою висловив авторську позицію щодо власної концептуальної позиції стосовно сутності порівняльної історії права і іï інтерпретації у варіанті «вітчизняна традиція концептуалізації». Головне - С.В. Кудін є достатньо обізнаний у теоретичних й методологічних аспектах порівняльного правознавства і порівняльної історії права, володіє непростим апаратом юридичної мови XIX ст., яка відображає змістовне наповнення порівняльної історії права в осмисленні українських учених зазначеного періоду.

Перший розділ монографічного дослідження присвячено стану дослідження поглядів вітчизняних учених на сутність порівняльної історії права й методології наукового вивчення проблеми. Даний розділ є, 3 одного боку, вступний, з іншого - важливий. Так, автор звертає увагу на не розробленість тематики, що, важливо підкреслити, актуалізує дослідження, залучає ті методи наукового пізнання, які повинні сприяти 
досягненню мети дослідження. Визнаємо, що С.В. Кудін достатньою мірою окреслив методологічний апарат дослідження, що й дозволило йому «перетворити» гіпотетичні припущення у доведені ним конструкції.

Другий розділ присвячено обгрунтуванню процесу становлення наукового осмислення порівняльної історії права у 40-х роках XIX - на початку XX ст. У ньому автор монографії визначив, що вітчизняна традиція концептуалізації порівняльної історії права забезпечена такими елементами, як стійкість, консерватизм, здатність до історичної пролонгації, «перетікання» форм у вигляді варіантів, можливості розвитку у майбутньому. С.В. Кудіним підкреслено як унікальність кожного варіанту вітчизняної традиції, так і схожість за основними критеріями: теоретико-методологічні розробки i ïх практичне втілення у працях М.Д. Іванишева, Ф.І. Аеонтовича, А.М. Стоянова,Ф.В. Тарановського та інших учених.

У третьому розділі С.В Кудін представив і логічно обгрунтував об'єктивно існуючу історичну «драму» занепаду порівняльно-історичних правових досліджень в УРСР, своєрідне «перетікання» таких наукових розробок за кордон, дослідив зміст порівняльноісторичних досліджень українських учень, що перебували за межами Радянської України. Головним здобутком автора монографії можна вважати визнання ним недискретного характеру розвитку вітчизняної традиції концептуалізації порівняльної історії права, так як праці учених «в екзилі» були своєрідним продовженням їх попередників.

Четвертий розділ містить вирішення автором дилемного питання щодо наступної проблем: яким чином встановлюється взаємозв`язок між поняттями «традиційність» i «новаційність» інтерпретації порівняльної історії права, а також - якими є перспективи іï розвитку в Україні на початку XXI ст. Імпонує, що автор монографічного дослідження обгрунтовує постулат взаємозв'язку зазначених понять оригінально: «традиційність» і «новацінійсть» пов'язані низкою різних форматів утвердження «традиційності» в часовому вимірі, а «новаційність» відображається у нашому уявленні через призму філософських понять «компаративного» $\mathrm{i}$ «постнекласичного».

У результаті, можна стверджувати, що монографія С. В. Кудіна «Порівняльна історія права: вітчизняна традиція концептуалізації» 6 тим науковим дослідженням, що має важливе значення для подальшого розвитку науки філософії права, порівняльного правознавства, теорії права і держави, історії держави і права України, історії держави і права зарубіжних країн, історії вчень про державу і право. 